\title{
Итмурундинский аккреционный комплекс, северное Прибалхашье: новые данные о геологическом строении, составе и современная геодинамическая интерпретация
}

\author{
Чёрный Р.И., ${ }^{1,}$, Сафонова И.Ю., ${ }^{1,2}$, Савинский И.А., ${ }^{1,2}$ Перфилова А.А., ${ }^{1,2}$, Петренко Н.А. ${ }^{1,2}$ \\ ${ }^{1}$ Институт геологии и минералогии им. В.С. Соболева СО РАН, Новосибирск, science@igm.nsc.ru \\ ${ }^{2}$ Новосибирский государственный университет, Новосибирск, ggd@аdmin.nsu.ru
}

Аннотация. В статье представлены новые данные о геологическом строении и составе Итмурундинского аккреционного комплекса, центральный Казахстан, северное Прибалхашье. Выделены основные разновидности магматических и осадочных пород, изучены структурные взаимоотношения между отдельными группами осадочных и магматических пород, полученные результаты рассмотрены с точки зрения современных моделей формирования аккреционных комплексов. Литологические ассоциации, структурные взаимоотношения и последовательность отложений магматических и осадочных пород соответствует моделям орогении Тихоокеанского типа и стратиграфии океанической плиты, разработанным на конвергентных окраинах западной Пацифики.

Ключевые слова: орогения Тихоокеанского типа, аккреция, базальты, пелагические кремни, хемипелагические осадки, песчаники, конодонты.

\section{The Itmurundy accretionary complex, northern Balkhash: new data on the geological structure, composition and their geodynamic implications}

\author{
Chyorny R.I. ${ }^{1,2}$, Safonova I.Y. ${ }^{1,2}$, Savinskiy I.A. ${ }^{1,2}$, Perfilova A.P. ${ }^{1,2}$, Petrenko N.A. ${ }^{1,2}$ \\ ${ }^{1}$ V.S. Sobolev Institute of Geology and Mineralogy, Novosibirsk, science@igm.nsc.ru \\ ${ }^{2}$ Novosibirsk State University, Novosibirsk,ggd@admin.nsu.ru
}

\begin{abstract}
Аннотация. The article presents new data on the geological structure and composition of the Itmurundi accretionary complex, central Kazakhstan, north Pribalkhash area. The main types of magmatic and sedimentary rocks of the investigated area have been identified, the structural relationships between individual groups of sedimentary and magmatic rocks have been studied, the results have been considered from the point of view of modern models of accretion complex formation. Lithologic associations, structural relationships and sequence of magmatic and sedimentary rocks corresponds to the models of Pacific-type orogeny and oceanic plate stratigraphy, developed on the western Pacific convergent margins.
\end{abstract}

Key words: Pacific-type orogeny, accretion, basalt, pelagic chert, hemipelagic sediments, sandstones, conodonts.

\section{Введение}

На северном побережье оз. Балхаш находится Итмурунды-Казыкская складчатая зона, расположенная в ядре Северо-Балхашского антиклинория центральной части Джунгаро-Балхашской складчатой системы (Геологическая карта СССР, 1960; Паталаха, Белый, 1981). Эта территория в окрестностях г. Итмурунды описывалась ранее как Итмурунды-Казыкская офиолитовая зона (Паталаха, Белый, 1981). Геологосъёмочные работы масштаба 1:200000 в Итмурундинской зоне проводились Министерством геологии и охраны недр СССР еще в 50-х годах прошлого столетия (Геологическая карта СССР, 1960). Наиболее детальная публикация по этому району - это глава «Офиолиты Итмурунды-Казыкской зоны» Е. И. Паталахи и В. А. Белого (1981) в монографии «Офиолиты Казахстана» под редакцией А.А. Абдулина и Е.И. Паталахи (1981), в которой представлены геологические данные. Эти данные показывают устойчивые повторяющиеся ассоциации пород (снизу-вверх): от базальтов к кремням, кремнистым аргиллитам, алевролитам и сланцам, и, наконец, к песчаникам. С конца 1990-х годов ряд исследователей уже описывали эту зону как аккреционный комплекс или аккреционную призму (Zhylkaidarov, 1998; Никитин, 2002; Степанец, 2015) и связывали её формирование с эволюцией Палеоазиатского океана и формированием Центрально-Азиатского складчатого пояса (ЦАСП) (Зоненшайн и др., 1990; Dobretsov et al., 1995). Возраст осадочных пород аккреци- 


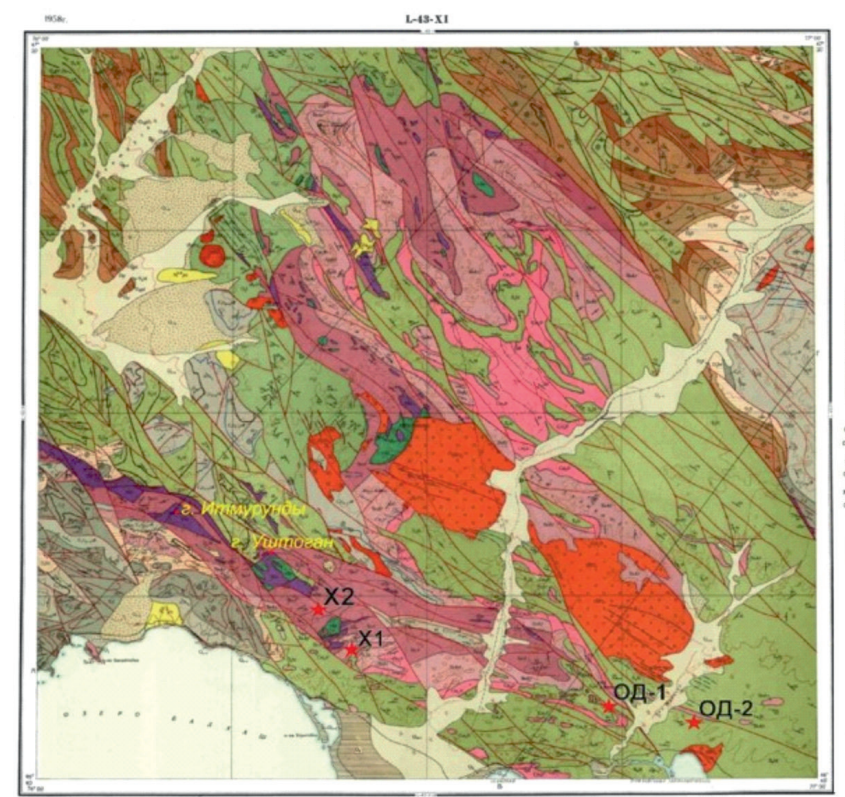

Условные обозначения

Верхнечетвертичный и современный отделы. Аллювиально-делювиальные пески, суглинки, щебни Верхнечетвертичный и современный отделы. Озерные отложения: илы, пески, галечники Среднечетвертичный отдел. Озерные отложения древних береговых валов-пески, глины, галечники Нижне- и среднечетвертичный отделы. Делювиально-пролювиальные суглинки, щебнистые отложения Миоцен. Павлодарская свита. Буро-красные мергели, глины, щебнистые отложения Визейский ярус. Средний и верхний подьярусы. Саякская свита. Конгпомераты, песчаники, зффузивы, известняки Турнейский ярус. Песчаники, эффузивы кислого состава

Фаменский ярус. Песчаники, эффузивы кислого состава, конгломераты, известняки Франский ярус. Песчаники, туфы Эйфельский ярус. Песчаники, туфы, туффиты Кобленцский ярус. Песчаники, туфы, туффиты Жединский ярус. Песчаники, туфы, алевролиты Лудловский ярус. Песчаники, конгломераты, известняки, туфы

Лландейльский ярус. Туфы смешанного состава, альбитофиры, порфириты, известняки Тюретайская свита. (Эффузивно-осадочная свита). Диабазы, алевролиты, яшмы, брекчии Казыкская свита. (Яшмовая свита). Яшмы, глинисто-кремнистые породы, песчаники Итмурундинская свита. (Спилитовая свита). Спилиты, диабазовые порфириты, яшмы, песчаники, кератофиры Дайки гранит-порфиров, гранодиорит-порфиров, граносиенит-порфиров Дайки кварцевых диоритовых порфиритов

Гипабиссальные тела гранодиорит-порфиров

Гипабиссальные интрузивы кварцевых диоритовых порфиритов

Граниты биотит-роговообманковые, гранодиориты, кварцевые диориты

Интрузивы габбро

Ультраосновные интрузивы

онного комплекса был установлен в интервале от ордовика до раннего силура по микропалеонтологическим данным (конодонтам, граптолитам) (Zhylkaidarov, 1998; Никитин, 2002).

К настоящему времени сохраняется большой дефицит современных высокоточных геохронологических и геохимических данных. Сотрудниками (ЛЭПОМ) ГГФ НГУ недавно опубликованы первые собственные данные по геологической структуре, литологии отложений и петрографии пород Итмурундинской зоны, которые обсуждаются с позиции орогении тихоокеанского типа (Сафонова и др., 2019). В данной работе представлены новые геологические данные по строению отложений стратиграфии океанической плиты (СОП) и геохимические данные по магматическим породам, входящим в состав СОП.

\section{Геологическое строение}

Итмурундинский аккреционный комплекс расположен в одном из наиболее пустынных мест обширной территории Северного Прибалхашья. Сразу же к северу от оз. Балхаш начинается мелкосопочник, разделенный сухими долинами. Местами среди мелкосопочника поднимаются невысокие горы из более устойчивых к выветриванию пород. Полевые работы проводились на участках Хорс-1 и Хорс-2, расположенных в 5-50 км на восток и юго-восток от г. Итмурунды, и на участках ОД-1 и ОД-2, расположенных, примерно, в 100 км к юго-востоку от г. Итмурунды. На геологической карте масштаба 1:200000, лист L-43-XI (Геологическая карта CCCP, 1960), можно выделить три главные ассоциации магматических и осадочных пород, имеющих возраст от позднего докембрия до кайнозоя: офиолиты (мантийная ассоциация), аккреционный комплекс (орогенная ассоциация) и континентальные отложения (пост-орогенная ассоциация). Породы мантийной ассоциации представляют собой нижнюю и среднюю части классического офиолитового разреза и включают серпентинитовый меланж с разнообразными ультраосновными породами (гарцбургит, дунит, верлит), габброидами и плагиогранитами.

Породы орогенной ассоциации с несогласием залегают на породах мантийной ассоциации и включают образования, сформированные в процессе орогении тихоокеанского типа (Maruyama et al., 2010). Это, в первую очередь, отложения океанической плиты, т.е. аккретированные фрагменты верхней части океанической коры или верхи офиолитового разреза. Породы орогенной ассоциации представлены базальтами, в том числе и пиллоу-лавами, кремнистыми осадочными породами океанического происхождения (кремни, аргиллиты, алевролиты, сланцы). Взаимоотношения этих пород друг с другом очень сложны, развиты многочисленные разломы разных порядков, разделяющие как литологически различные, так и одинаковые толщи пород. Отсутствие понимания закономерностей формирования и строения этих толщ геологами, изучавшими эту зону в середине прошлого столетия, привело к появлению термина «хаотические толщи», которые в современной терминологии называются аккреционными. 
Орогенная ассоциация перекрыта породами пост-орогенной ассоциации, сформированными после закрытия океана. Они представляют собой терригенные, преимущественно континентальные осадочные образования (алевролиты, песчаники, гравелиты, конгломераты, известняки). Ранее они рассматривались как фаменская неоавтохтонная олистострома или фаменский базальный горизонт. Олистострома постепенно сменяется гравелитами и зеленовато-серыми песчаниками и алевропесчаниками с прослоями аналогичных пород лилового цвета. Выше несогласно залегает раннекаменноугольная толща сероцветных и пестроцветных полимиктовых конгломератов, гравелитов, песчаников и алевролитов, углистых алевролитов с полимиктовыми песчаниками.

\section{Структурно-вещественная характеристика пород}

Были изучены основные разновидности магматических и осадочных пород Итмурундинского аккреционного комплекса. Главная разновидность магматических пород - базальты, встречающиеся в виде фрагментов потоков и пиллоу-лав; часто изменены - видны прожилки эпидота, кварца, гидроокислы железа, псевдоморфозы лимонита по пириту. Базальты имеют массивную, реже миндалекаменную текстуру, афировую или порфировую структуру. Наиболее распространенными являются толеитовые и щелочные базальты. В порфировых разновидностях вкрапленники представлены пироксеном и плагиоклазом. Основная масса имеет интерсертальную структуру. Миндалекаменные разновидности с миндалинами, заполненными цеолитами и кальцитом. По содержанию породообразующих окислов они соответствуют базальтам и андезибазальтам толеитовой серии и щелочным базальтам. По редким элементам выделяются две основные разновидности базальтов - океанических островов (тип OIB) и срединно-океанических хребтов (тип MORB). Для базальтов группы MORB характерны умеренные содержания $\mathrm{TiO}_{2}$ и практически плоские спектры распределения редкоземельных элементов (REE). В базальтах группы OIB заметно выше содержания $\mathrm{TiO}_{2}$ и $\mathrm{Nb}$ и спектры REE больше обогащены легкими компонентами (Петренко и др, 2018).

Структурно выше залегают сургучно-красные, бурые и зеленоватые кремни, часто измененные до яшмоидов и микрокварцитов. Глубоководная природа этих кремней определена по находкам в них радиолярий и конодонт (Zhylkaidarov, 1998) и по крайне тонкозернистой, фактически криптокристаллической структуре. Кроме того, кремни очень часто имеют ленточную текстуру, что характерно для глубоководных пелагических кремней, описанных в составе древних и молодых аккреционных комплексов западной Пацифики (Isozaki et al., 1990). Нами из кремней были выделены конодонты, которые показали возраст от верхов среднего ордовика до низов позднего ордовика (Сафонова и др., 2019). Эти кремни относятся нами к пелагическим образованиям. На кремнях залегают мощные толщи кремнистых аргиллитов шоколадного, лилового и серо-зеленого цвета и алевролитов оливково-бурого и серо-зеленого цвета. Местами аргиллиты также находятся в контакте с пиллоу-лавами. Кремнистые аргиллиты, алкевролиты и сланцы образовались в хемипелагических обстановках. Завершается разрез массивными мелко- до крупнозернистыми граувакковыми песчаниками, имеющими серо-зеленый цвет. Песчаники состоят из обломков основных вулканических пород, кремней, полевых шпатов и темноцветных пород и накапливались либо в преддуговой обстановке, либо в глубоководном желобе. Песчаники имеют андезитовый и дацитовый составы. По классификации Неелова (1980) они соответствуют грауваккам.

\section{Геодинамическая интерпретация}

Изученные обнажения базальтов, кремней, кремнистых аргиллитов и алевролитов, и песчаников, их закономерные структурные взаимоотношения, т.е. нахождение базальтов в основании разрезов, их перекрытие кремнями и/или кремнистыми аргиллитами и алевролитами, и завершение разрезов песчаниками подтверждает соответствие этих ассоциаций пород модели стратиграфии океанической плиты (СОП). Эта модель была разработана японскими учеными по результатам многолетнего изучения аккреционных комплексов японских островов (Isozaki et al., 1990). COП представляет собой закономерную последовательность магматических (MORB, базальты срединноокеанических хребтов; OIB, базальты океанических островов; габбро и перидотиты) и осадочных (пелагические кремни, хемипелагические кремнистые осадки, турбидиты глубоководного желоба, симаунт: карбонатная «шапка», фации склонов и основания) пород океанической литосферы, которые соответственно изливались или отлагались на океаническом дне по мере того, как она двига- 
лась от срединно-океанического хребта к зоне субдукции. В процессе океанической субдукции толщи СОП причленяются к активным окраинам и входят в состав аккреционных комплексов. Фрагменты океанической коры или элементы СОП являются важными компонентами орогенных поясов Тихоокеанского типа (Isozaki et al., 1990; Windley et al., 2007). Присутствие в Итмурундинской зоне пород СОП и их сложные взаимоотношения, наличие структур типа «дуплекс» и «хорс», а также многочисленные надвиги и поддвиги подтверждают аккреционную природу этой зоны и ее образование на конвергентной окраине тихоокеанского типа Палеоазиатского океана.

\section{Заключение}

Итмурундинский аккреционный комплекс заключает в себе большое количество информации об ордовикском этапе эволюции Палеоазиатского океана. Он включает в себя породы стратиграфии океанической плиты, в которой зафиксирована вся история океанической плиты этого древнего палеоокеана от её появления в срединно-океаническом хребте до исчезновения в зоне субдукции. Изученные ассоциации вулканических и осадочных пород представляют собой полный разрез СОП: базальты типа MORB и OIB - кремни (пелагические отложения) - кремнистые аргиллиты, алевролиты и сланцы (хемипелагические отложения) - отложения глубоководного желоба (турбидиты) и передовой дуги (граувакки). По структурному положению и литологическому составу они соответствуют модели образования аккреционных комплексов на конвергентных окраинах тихоокеанского типа западной Пацифики. В настоящее время наши исследования сфокусированы на детальном выяснении пространственно-временных взаимоотношений различных пород, геохронологических и изотопно-геохимических исследованиях. Исследования проводились в рамках проекта Минобрнауки № 14.Ү26.31.0018 «Мультидисциплинарное изучение складчатых поясов тихоокеанского типа и создание согласованной модели эволюции океанов, их активных окраин и мантийного магматизма» лабораторией эволюции палеоокеанов и мантийного магматизма (ЛЭПОМ) ГГФ НГУ.

\section{Литература}

1. Геологическая карта СССР масштаба 1:200 000. Серия Прибалхашская, лист L-43-XI, ВСЕГЕИ / ред. Соловьева Л.Д., Семенов А.Ф. Санкт-Петербург. 1960. С. 67.

2. Ермолов П.В., Степанец В.Г., Сеитов Н. Офиолиты Казахстана // Путеводитель экскурсии международного рабочего совещания по проекту 2: «Офиолиты». Караганда. 1990. 67 с.

3. Зоненшайн Л.П., Кузьмин М.И., Натапов Л.М., 1990. Тектоника литосферных плит СССР. Т. І. М. Изд-во: Недра. 328 c.

4. Никитин И.Ф. 2002. Ордовикские кремнистые и кремнисто-базальтовые комплексы Казахстана. Геология и геофизика. 43. С. 512-527.

5. Паталаха Е.А., Белый В.А. Офиолиты Итмурунды-Казыкской зоны // Офиолиты Казахстана. Алма-Ата. 1981. C. 7-102.

6. Петренко Н.А., Перфилова А.А., Сафонова И.Ю., Котлер П.Д., Чёрный Р.И., Маруяма Ш. Вулканические и терригенные породы Итмурундинского аккреционного комплекса, северное Прибалхашье: петрография, геохимия и тектонические обстановки формирования. Материалы X Всероссийской научной конференции с международным участием «Петрология магматических и метаморфических комплексов», 27-30 ноября, 2018 г. Томск. 2018. Изд-во: Томского ЦНТИ. Вып. 10. С. 428-432.

7. Сафонова И.Ю., Перфилова А.А., Обут О.Т., Савинский И.А., Чёрный Р.И., Петренко Н.А., Гурова А.В., Котлер П.Д., Хромых С.В., Кривоногов С.К., Маруяма Ш., 2019. Итмурундинский аккреционный комплекс (северное Прибалхашье): геологическое строение, стратиграфия и тектоническое происхождение // Тихоокеанская геология. № 3. С. 102-117.

8. Степанец В.Г. Офиолиты Казахстана. Геология и геодинамика. 2016. Т. II. LAP Lambert Academic Publishing. $251 \mathrm{p}$.

9. Dobretsov N.L., Berzin N.A., Buslov M.M. Opening and tectonic evolution of the Paleo-Asian Ocean // International Geology Review. 1995. V. 35. P. 335-360.

10. Isozaki Y., Maruyama S., Fukuoka F. Accreted oceanic materials in Japan // Tectonophysics. 1990. C. 179-205.

11. Maruyama S., Kawai T., Windley B.F. Ocean plate stratigraphy and its imbrication in an accretionary orogen: The Mona complex, Anglesey-Lleyn, Wales, UK // Geological Society, London, Special Publications. 2010. V. 338. P. 55-75.

12. Windley B.F., Alexeiev D., Xiao W., Kröner A., Badarch G. Tectonic models for accretion of the Central Asian Orogenic Belt // Journal of the Geological Society. 2007. V. 164. P. 31-47.

13. Zhylkaidarov A.M. On the age of volcanogenic-cherty deposits of Dzhungar-Balkhash region on conodonts // Vestnik AN Kazahskoj SSR 5. 1988. C. 84-86. 